\title{
DESJUDICIALIZAÇÃO: AQUISIÇÁO DA PROPRIEDADE IMÓVEL PELO PROCEDIMENTO DE USUCAPIÃO EXTRAJUDICIAL
}

\author{
DISCHARGING: \\ ACQUISITION OF PROPERTY IMPOSED BY THE \\ EXTRAJUDICIAL USUCATION PROCEDURE
}

\author{
GILBERTO FERREIRA MARCHETTI FILHO ${ }^{1}$ \\ ANA JULIA MUNIZ LEMES ${ }^{2}$
}

\section{RESUMO}

Com a entrada em vigor do Código de Processo Civil (Lei Federal n 13.105/2015), originou-se a possibilidade da usucapião extrajudicial, ou seja, do interessado buscar a declaração da usucapião da propriedade imobiliária diretamente nas serventias extrajudiciais, sem a necessidade de se recorrer ao Judiciário. Trata-se, em verdade, da busca pelo novo processo civil da adequação dos meios de solução de conflito, a fim de se promover a pacificação social com acesso à justiça efetiva, justa, eficiente e adequada. Nessa ideia, a usucapião extrajudicial visa exatamente essa desjudicialização dos conflitos, facilitando a aquisição da propriedade imóvel. Contudo, passado alguns anos da sua vigência, cabe analisar, por uma revisão bibliográfica e de legislação específica, o instituto sob uma visão de aplicabilidade prática e apontar possíveis questões que possam prejudicar sua atuação efetiva na sociedade.

PALAVRAS-CHAVE: Pacificação social. Adequação nos meios de solução de conflito. Desjudicialização. Usucapião extrajudicial.

\section{ABSTRACT}

With the entry into force of the Code of Civil Procedure (Federal Law n. 13.105/2015), originated the possibility of adverse possession, that is, of the interested party seeking the declaration of the possession of real estate property directly in the extrajudicial services, without the necessity of if you turn to the Judiciary. It is, in fact, the search for the new civil procedure to adapt the means of conflict resolution, in order to promote social pacification with access to effective, just, efficient and adequate justice. In this idea, the adverse possession aims at exactly this misjudicialization of the conflicts, facilitating the acquisition of the immo-

1 Mestre em Processo Civil e Cidadania pela Universidade Paranaense - UNIPAR em 2018. Bacharel em Direito em 2004 e pós-graduado lato sensu em Direito Civil e Processo Civil em 2006, pelo Centro Universitário da Grande Dourados - UNIGRAN. Assessor Jurídico do Gabinete da 6a Vara Cível de Dourados - MS desde 2005. Professor de Direito Civil no Centro Universitário da Grande Dourados - UNIGRAN desde 2006 e Direito Processual Civil em cursos de pós-graduação. gilberto. marchetti@unigran.br.

2 Acadêmica do Curso de Direito do Centro Universitário da Grande Dourados - UNIGRAN. anajuliamunizlemes@hotmail.com. 
vable property. However, after a few years of its validity, it is necessary to analyze, through a bibliographic and specific legislation review, the institute under a vision of practical applicability and to point out possible issues that may hinder its effective action in society.

Keywords: Social pacification. Adequacy in means of conflict resolution. Disqualification. Adverse possession.

\section{INTRODUÇÁO}

O cenário jurídico atual tem trazido a grande importância do estudo e criação de novas formas de solução de conflitos com a finalidade de se promover uma solução adequada em tempo razoável e de forma justa e efetiva.

Nesse sentido, a entrada em vigor do Código de Processo Civil de 2015 trouxe, dentre outros fatores, a desjudicialização do procedimento de declaração da usucapião da propriedade imobiliária.

Entrementes, passado alguns anos de sua vigência, tem-se em evidência a questão da aplicabilidade prática do instituto, ou seja, se ele efetivamente está atendendo sua finalidade e, se não está, quais os fatores que podem influenciar nessa (in)aplicabilidade.

Dessa forma, este artigo possui como finalidade analisar o procedimento da usucapião extrajudicial, a causa do seu surgimento e sua aplicabilidade (ou não) prática dentro da proposta que lhe foi dada.

Com base nessa problematização e traçado esse objetivo, observando metódica dedutiva, sistêmica e axiológica, serão pontuadas considerações sobre a propriedade e a usucapião, dentro do seu fundamento constitucional, assim como a ideia da pacificação social dos conflitos dentro de uma visão de adequação dos meios de solução, apresentando, nisso, a desjudicialização dos conflitos.

Ao depois, tratar-se-á da usucapião extrajudicial, seu procedimento e sua aplicabilidade, bem como se realizará, por meio de uma revisão bibliográfica e de legislação específica, alguns apontamentos de possíveis causas para a inefetividade do instituto.

\section{A PROPRIEDADE E SUA FUNÇÃO SOCIAL}

O legislador brasileiro não ofereceu o conceito de propriedade, limitando-se apenas a elencar, no artigo 1.228 do Código Civil, os poderes inerentes a condição de proprietário como a faculdade de usar, gozar e dispor da coisa, e seu direito de reavê-la do poder de quem quer que injustamente a possua ou detenha (BRASIL, 2002).

Trata-se de direito real por excelência, o eixo em torno do qual gravita o direito das coisas. É, assim, o "mais completo dos direitos subjetivos, a matriz dos direitos reais e o núcleo dos direitos das coisas" (GONÇALVES, 2018, p. 223). 
Dessa forma, o conceito de propriedade, embora não aberto, há de ser indispensavelmente dinâmico. Deve-se reconhecer "que a garantia constitucional da propriedade está submetida a um intenso processo de relativização, sendo interpretada, fundamentalmente, de acordo com parâmetros fixados pela legislação ordinária" (GONÇALVES, 2018, p. 223).

Dentro desse campo, o princípio da função social da propriedade é, sem dúvida, um dos maiores fatores de limitação do direito da propriedade. Isso porque na evolução histórica de seu conceito, a propriedade que era plena, exclusiva e ilimitada passa a ser submetida ao interesse público e social, dentro de um fenômeno chamado pela doutrina e jurisprudência como publicização do direito privado ${ }^{3}$.

Diante disso, tem-se que a Constituição Federal garante a todos o direito de propriedade em seu artigo $5^{\circ}$, inciso XXII. Porém, logo em seguida, no inciso XXIII, relativiza-o ao determinar que a propriedade atenderá a sua função social (BRASIL, 1988).

Essa noção também está inserida no próprio Código Civil ao dispor no artigo 1.228, § $1^{\circ}$, que "o direito de propriedade deve ser exercido em consonância com as suas finalidades econômicas e sociais" (BRASIL, 2002).

Contudo, analisar a função social não é uma tarefa simples. "Trata-se de expressão que a própria doutrina reconhece ser de conteúdo vago. Porém, ainda que genericamente, pode ser interpretada como a subordinação de certo instituto ao seu interesse social ou coletivo, dentro de uma determinada sociedade" (MARCHETTI FILHO, 2018b, p. 99).

No aspecto geral, função, guarda a "noção de um poder de dar destino determinado a um objeto ou a uma relação jurídica, de vinculá-los a certos objetivos; o que, acrescido do adjetivo 'social', significa dizer que esse objetivo ultrapassa o interesse do titular do direito - que, assim, passa a ter um poder-dever - para revelar-se como de interesse coletivo" (GODOY, 2004, p. 111).

Portanto, em linhas simples, "falar-se em função social de um direito, significa dizer sua atuação ou reflexão de seus efeitos dentro do seio da sociedade em que está inserido, deixando de lado seu aspecto exclusivamente individualista, e observando uma noção coletiva de sua incidência" (MARCHETTI FILHO, 2018a, p. 78).

Diante disso, trazendo essa ideia para o campo da propriedade, a função social relativiza a propriedade, transformando o conceito do jus abutendi do direito romano, no sentido de que hoje o proprietário não pode mais, dentro do direito de dispor, fazer o que quiser. "A disposição da coisa deve se dar à luz da Constituição Federal, dentro da função social da propriedade" (MARCHETTI FILHO, 2018a, p.76).

Assim, o direito de propriedade continua sendo um direito fundamental, representando a característica máxima da "individualidade e patrimonialidade humana, mas que, no seu exercício, deve observar uma função dentro da sociedade em que está inserido, em flagrante contrariedade ao individualismo extremo do século XIX, com um conceito absoluto de propriedade" (MARCHETTI FILHO, 2018a, p. 78).

3 "Aliás, há 'tendência moderna de intersecção dos regimes jurídicos próprios do Direito Público e Privado. A todo instante vem crescendo a publicização do Direito Privado [...] e, por outro lado, a privatização do Direito Público'. De conseguinte, dentro da ideia de solidarismo social, já mencionada, necessária ao Estado Constitucional de Direito, 'o princípio da dignidade da pessoa humana culmina por descortinar a nova vocação do Direito Privado, qual seja, a de redirecionar o alcance de suas normas para a proteção da pessoa, sem prejuízo dos mecanismos reguladores da proteção ao patrimônio"' (MARCHETTI FILHO, 2018b, p. 94-95). 
Enfim e sinteticamente, a função social da propriedade pode ser compreendida como o conjunto de requisitos mínimos estabelecidos pelo legislador para que se considere que o exercício do domínio atende ao interesse coletivo, sob pena de adoção das medidas sancionatórias previstas no ordenamento.

\section{BREVES NOÇÓES SOBRE A USUCAPIÁO}

Descritas entre os artigos 1.238 a 1.274 do Código Civil (BRASIL, 2002), os modos de aquisição da propriedade móvel e imóvel pode se dar de forma originária ou derivada. $\mathrm{Na}$ primeira, a aquisição se dá de forma que não se vincula com a propriedade anterior. É dizer, não há ato de transmissão da propriedade de um sujeito para o outro. Já na segunda, existe vinculação, decorrente de um ato de transmissão da propriedade. Esse ato resulta de uma relação entre dois sujeitos, como um negócio jurídico, por exemplo.

Nesses termos, a doutrina majoritária tem compreendido a usucapião como modo de aquisição originária da propriedade ${ }^{4}$, estritamente ligada ao tempo. "De fato, o tempo pode provocar a extinção de um direito, ou sua aquisição. Trata-se da prescrição, como gênero em que tem como espécie a prescrição extintiva, tratada no artigo 189 do Código Civil, e a prescrição aquisitiva, aqui tratada como usucapião" (MARCHETTI FILHO, 2018a, p. 88).

Modernamente tem se compreendido que, no âmbito constitucional, a usucapião tem por fundamento a função social da propriedade. Isso porque busca dar a propriedade àquele que efetivamente está trazendo a ela uma utilidade social e econômica à propriedade (MARCHETTI FILHO, 2018a, p. 88).

Deveras, a função social da propriedade "contempla, ao mesmo passo, um conjunto de faculdades e um conjunto de deveres positivos e negativos, não mais expressando pura e simplesmente uma situação de poder, por si só e abstratamente considerada" (CHALHUB, 2000, p. 12).

Nessa linha de pensamento, pela usucapião, dentro da função social, "premia-se aquele que dá efetivamente utilidade à coisa, em detrimento do proprietário que, diante de sua desídia, deixa passar tempo suficientemente considerável sem dar qualquer destinação social ou econômica a ela" (MARCHETTI FILHO, 2018a, p. 88).

Compreendido isso, tem-se que a usucapião deve atender pressupostos de natureza pessoal, real e formal. Os de natureza pessoal são requisitos acerca da legitimidade ativa e passiva.

Nesse aspecto, dentro da perspectiva do artigo 1.241 do Código Civil" , "a legitimidade ativa é do possuidor com posse ad usucapionem, ou seja, com intenção de usucapir. E a legitimidade passiva é da pessoa que figura como proprietário na matrícula do imóvel" (MARCHETTI FILHO, 2018a, p. 89).

4 Caio Mario da Silva Pereira (2008, p. 138) entende que a usucapião é modo de aquisição derivada da propriedade

5 Art. 1.241. Poderá o possuidor requerer ao juiz seja declarada adquirida, mediante usucapião, a propriedade imóvel. (BRASIL, 2002) 
Demais disso, deve-se observar as limitações impostas por força do artigo 1.244 do Código ${ }^{6}$, que impedem certas pessoas de usucapir por não contar o respectivo prazo, tais como "entre ascendentes e descendentes, durante o poder familiar" e "entre tutelados ou curatelados e seus tutores ou curadores, durante a tutela ou curatela" (BRASIL, 2002), na forma do artigo 197, inciso II e III.

Por sua vez, os requisitos reais referem-se aos bens e direitos suscetíveis de serem usucapidos, visto que nem todas as coisas podem ser objeto da usucapião. Isso porque alguns bens são insuscetíveis de serem usucapidos em razão de sua natureza (como o ar e a luz), ou porque estão fora do comércio, ou ainda por ser bem público?.

Já os pressupostos formais possuem relação com os requisitos gerais indispensáveis e costumeiros da usucapião, como a posse, o lapso temporal e o animus domini, bem como os específicos de cada modalidade, como o justo título e a boa fé, ou o tamanho da área do imóvel, ou ainda, a forma de sua utilização.

É de se considerar ainda que a posse ad usucapionem, isto é, "a que se prolonga no tempo, a tal ponto que é capaz de gerar a aquisição da propriedade pela prescrição aquisitiva" (MARCHETTI FILHO, 2018a, p. 54), deve condizer com o animus domini, ser mansa e pacificamente, contínua e publicamente, ao longo do prazo definido na lei. A ausência disso impede a usucapião.

A título de parêntese, vale lembrar que a posse mansa e pacífica é a praticada sem a oposição do proprietário contra quem pretende usucapir. Logo, observado que o dono da coisa se opôs de alguma forma à posse do possuidor, essa deixará de ter a qualidade de incontestada e passará a não preencher os requisitos básicos para usucapir (MARCHETTI FILHO, 2018a, p. 51). E compreende contínua a posse desempenhada sem interrupções.

Do mesmo modo, a posse também não pode prejudicar o proprietário que está na defesa de seu domínio. Por conseguinte, para caracterizar isso, é preciso que o possuidor não viole os direitos do proprietário da coisa e esse seja inerte, passivo em relação a essa situação fática, sem tentar recuperar a coisa para si.

Ainda referente ao tema, é reconhecida possibilidade da sucessão na posse para fins de contagem do prazo da usucapião, na forma do artigo 1.243 do Código Civil. Nessa linha de contada, "o possuidor pode, para o fim de contar o tempo exigido pelos artigos antecedentes, acrescentar à sua posse a dos seus antecessores (artigo 1.207), contanto que todas sejam contínuas, pacíficas e, nos casos do artigo 1.242, com justo título e de boa-fé" (BRASIL, 2002).

Cumpre notar que a posse há de ser justa, sem os vícios da violência, clandestinidade ou precariedade, na medida em que se a situação de fato for resultante desses meios, não induzirá a posse enquanto os efeitos não cessarem. E, se for adquirida a título precário, não se modificará em posse justa de forma alguma.

6 Art. 1.244. Estende-se ao possuidor o disposto quanto ao devedor acerca das causas que obstam, suspendem ou interrompem a prescrição, as quais também se aplicam à usucapião. (BRASIL, 2002)

7 A despeito de existir alguma divergência sobre a possibilidade de usucapião em relação a bens públicos dominiais, o entendimento ainda dominante na doutrina e jurisprudência é no sentido de que "os bens públicos não estão submetidos à possibilidade de prescrição aquisitiva ou, em uma palavra, os bens públicos não se sujeitam a usucapião" (MAZZA, 2015, p. 711). 
Diante disso, entende-se por posse mansa ou pacífica, para os efeitos da usucapião, aquela alcançada sem a oposição do proprietário do bem. É dizer, o proprietário tem conhecimento de que sua posse foi violada. Entretanto, permanece inerte, nada fazendo para possibilitar sua recuperação, seja de forma judicial ou extrajudicial.

Isto é, não afasta o invasor, não propõe o remédio possessório correspondente. Simplesmente "conforma-se com a perda. Ora, proprietário que assim age, omitindo-se revela desinteresse pelo bem e, com isso, abre espaço para que outro a ocupe e utilize. Quem, diante de uma agressão à posse, conserva-se inerte, revela seu descaso para com ela" (MARQUESI, 2018, p. 30).

De outro norte, por se tratar de prescrição aquisitiva, o lapso temporal é uma das exigências para a consumação da usucapião. Com efeito, em seus fundamentos, observa-se que "o tempo exerce uma força aquisitiva, embora seja também causa de perda da propriedade ou do direito real do antigo titular" (MARQUESI, 2018, p. 26). Esse lapso pode variar a depender da modalidade do instituto.

Enfim. É certo que, num olhar superficial, há o pressentimento de que a usucapião ofende o direito de propriedade, a partir do momento em que o possuidor passa a ocupar a coisa, perdendo o direito de dominus.

Contudo, como vimos, dentro do aspecto da função social da propriedade, existe um motivo por trás dessa situação jurídica que fundamenta esse fato. Sobre esse tema, há duas correntes explicativas: a subjetiva e a objetiva.

A primeira, chamada de subjetiva, está representada na ideia da passividade do proprietário. Por ela, presume-se o ânimo da renúncia ao direito da propriedade, ou seja, considera-se que ele deixou de se interessar pelo bem, dele abrindo mão.

Por outro lado, a corrente objetiva tem base na função social da propriedade, reconhecida constitucionalmente como dever do proprietário no exercício da sua propriedade. Trata-se da corrente modernamente aceita, na visão constitucional, como observado anteriormente.

Dessa forma, a partir do momento em que o possuidor confere ao bem uma utilidade, "dando-Ihe uma função socioeconômica, particularidade que, como se sabe, é o fundamento do instituto em comento" (MARQUESI, 2018, p. 31), a usucapião não ofende a propriedade. Pelo contrário, a fortalece na visão constitucional.

\section{A NECESSIDADE DA PACIFICAÇÃO DOS CONFLITOS SOCIAIS E O CÓDIGO DE PROCESSO CIVIL}

O Estado possui o poder-dever de, por meio da tutela jurisdicional, proporcionar a pacificação dos conflitos sociais e, não menos, desempenhar o papel da justiça. Deveras, o acesso à justiça não é apenas o direito fundamental de se ingressar com uma ação. Vai muito além. Representa, dentro do Estado Constitucional de Direito, o acesso à justiça efetiva, justa, eficiente e adequada, na promoção da pacificação do conflito, não apenas no aspecto jurídico, mas no social e no psíquico (MARCHETTI FILHO, 2018c). 
Contudo, o que se pode verificar ao longo desse processo, é que o Judiciário não tem contribuído de forma efetiva, com justiça e eficiência no que concerne à resolução das lides, restando prejudicada exatamente essa ideia da pacificação do conflito.

Mesmo porque "pacificar, antes de ser uma tarefa simples, implica uma complexidade ímpar. 'Por envolver o alcance de um estado de espírito humano, abrange aspectos não apenas jurídicos, mas sobretudo psicológicos e sociológicos'" (MARCHETTI FILHO, 2018c, p. 203).

Nesse sentido, é necessário ressaltar "ao mesmo tempo em que o legislador assegura o acesso irrestrito à justiça, preconiza também as virtudes da solução consensual dos conflitos, atribuindo ao Estado o encargo de promover essa prática pacificadora, sempre que possível" (THEODORO JÚNIOR, 2015, v. 1, p. 76).

Não se trata de desacreditar a Justiça estatal, mas de combater o excesso de litigiosidade que domina a sociedade contemporânea, que crê na jurisdição como única via pacificadora de conflitos, elevando a um número tão gigantesco de processos aforados, que supera a capacidade de vazão dos órgãos e estruturas do serviço judiciário disponível. Em diversos países, a cultura tem desviado grande parte dos conflitos para mecanismos extrajudiciais, como a mediação e a conciliação, que além de aliviar a pressão sobre a justiça pública, se apresentam em condições de produzir resultados substancialmente mais satisfatórios do que os impostos pelos provimentos autoritários dos tribunais. (THEODORO JÚNIOR, 2015, v. 1, p. 76)

Demais disso, há que se considerar que, nos dias de hoje, existe certa "priorização de certos aspectos do processo, para os quais o sistema tradicional não dava solução. Os casos mais evidentes são relacionados ao acesso à justiça e à lentidão dos processos, bem como a distribuição dos ônus decorrentes da demora na solução dos conflitos" (GONÇALVES, 2017, p. 44).

Mas não é só. "Há ainda a questão da socialização da justiça, relacionada ao fato de muitos conflitos de interesses deixam de ser levados a juízo, seja em virtude do custo que isso demanda, seja porque o interesse não tem lesado direito, pois o dano se pulveriza entre toda a sociedade" (GONÇALVES, 2017, p. 44).

Importante destacar, nessa linha de raciocínio, que o Código de Processo Civil de 2015 tem como norte "'uma valoração do consenso e uma preocupação em criar no âmbito do Judiciário um espaço não apenas de julgamento, mas de solução de conflitos', tendo em vista a pacificação" (MARCHETTI FILHO, 2018c, p. 213).

Com efeito, busca, dentro dessa visão de solução de conflitos, propiciar um '"um redimensionamento e democratização do próprio papel do Poder Judiciário e do modelo de prestação jurisdicional pretendido'" (MARCHETTI FILHO, 2018c, p. 213).

Diante disso, é possível destacar "basicamente quatro fatores para se colocar a Codificação de 2015 como instrumento de pacificação social: a) a boa-fé objetiva; b) a cooperação; c) modernização do contraditório; e d) a adequação dos meios de resolução de conflitos" (MARCHETTI FILHO, 2018c, p. 213).

Nesse sentido, inaugura-se com a vigência do atual Código de Processo Civil a tendência de meios adequados para as soluções de conflito. A sua pacificação deve ser incentivada 
pelos operadores do direito, para que a cada dia seja mais aplicada caso a caso, dentro da ideia de solução adequada de conflitos.

\section{OS MECANISMOS ADEQUADOS DE RESOLUÇÃO DE CONFLITOS}

Como dito, o quarto fator que promove a pacificação social é a adequação dos meios de solução conflitos oferecidos pela legislação processual. E nesse ponto, o Código de Processo Civil ganhou destaque.

Isso porque, por ele, os meios disponíveis para a resolução de um conflito, seja pela autocomposição (conciliação ou mediação), seja pela heterocomposição (arbitragem ou processo em específico), "devem ser considerados pela seguinte premissa: o meio deve ser adequado à solução do conflito posto para a promoção da pacificação social" (MARCHETTI FILHO, 2018c, p. 224).

Logicamente que, nesse enfoque, a mediação, a conciliação e a arbitragem ganham destaque, exatamente por, dentro de suas especificidades, retirarem do Estado o poder de decidir o conflito.

Ante a ineficiência na prestação estatal da tutela jurisdicional, especialmente pelo perfil contencioso e pela pequena efetividade em termos da pacificação real das partes, os meios diferenciados vêm deixando de ser considerados "alternativos" para passar a integrar a categoria de formas "essenciais" de composição de conflitos (jurídicos e psicológicos), funcionando como efetivos equivalentes jurisdicionais ante a substituição da decisão do juiz pela decisão conjunta das partes. (TARTUCE, 2018, p 149)

Diante dessa realidade, constata-se um interesse maior do próprio Estado na busca de medidas menos formais, que viabilizem a garantia de reparar o bem jurídico lesado, promovendo a solução do conflito de forma adequada e, assim, a pacificação social .

Para cada espécie de conflito deve ser adotada a via adequada para a sua abordagem, considerando-se vários fatores, como, por exemplo, a intenção das partes, o perfil da controvérsia e as possibilidades inerentes a cada mecanismo que pode ser aplicado caso a caso.

É nesse contexto que surge o fenômeno da desjudicialização do conflito, a se tratar a seguir.

8 "A proposta da política judiciária que incentiva o desenvolvimento de vias diversas é criar, paralelamente à administração da justiça tradicional, novas vias de solução de litígios, preferencialmente por meio de instituições leves, relativa ou totalmente desprofissionalizadas (algumas vezes, até vedando a participação de advogados); a utilização deve ser barata - senão mesmo gratuita - e localizada de modo a facilitar (e maximizar) o acesso aos serviços, operando de forma simplificada e pouco regulamentada para obter soluções mediadas entre as partes" (TARTUCE, 2018, p 176). 


\section{ONDAS DE APERFEIÇOAMENTO DA JUSTIÇA: A TÉCNICA DA DESJUDICIALIZAÇÃO}

A técnica processual prevista do Código de Processo Civil de 1973 era essencialmente de judicialização dos conflitos. Isso porque essência era baseada no individualismo e patrimonialismo que imperavam no Século XIX na Europa e que vieram para o Brasil por Enrico Tulio Liebman.

Por isso, a tutela processual do Código de 1973 era extremamente rígida, buscando satisfatividade pela decisão judicial definitiva de mérito. E, decorrente desse rigorismo científico, é que não se tinha a previsão original de tutelas provisórias ou a abertura para outros meios de solução de conflitos.

Logicamente que, em tempos modernos, essa visão de processo e de judicialização de conflitos não atendia mais os anseios da sociedade, notadamente porque o próprio Poder Judiciário já não dá conta de se pronunciar satisfatoriamente e em tempo razoável em toda a demanda processual que recebe diariamente. A necessidade de uma mudança era premente.

Seguindo essa linha, entende-se a razão do Código de Processo Civil de 2015, além de abolir determinados institutos previstos no Código de 1973 e modernizar outros, permitiu a opção da extrajuducialização na usucapião imobiliária.

Nesse sentido, a expressão "desjudicialização" diz respeito ao fenômeno legislativo que traz às partes a possibilidade de solucionarem seus conflitos fora da esfera judicial, desde que possuam capacidade jurídica e que tenham por objeto direitos disponíveis. Trata-se da busca de soluções de conflitos sem intervenção dos tribunais.

No campo mais específico ao tema aqui proposto, a desjudicialização aponta a transferência facultativa de algumas atividades que, até então, eram atribuições específicas do Poder Judiciário, para o âmbito das serventias extrajudiciais, admitindo que estes órgãos possam solucionar o conflito por meio de procedimentos administrativos.

De fato, o Código de Processo Civil de 2015 não muda "o panorama na hipótese de o processo de usucapião perfazer-se em juízo, malgrado tenha suprimido algumas etapas antes necessárias. Mas abre a possibilidade do manejo pela via extrajudicial, certamente para evitar a complexidade e delonga da judicialidade" (MARQUESI, 2018, p. 51).

Esse processo legislativo de transferência da solução de alguns conflitos e de certas questões para os cartórios extrajudiciais - que antes só o Judiciário teria competência para fazê-lo - tem como propósito priorizar a celeridade na sua resolução, notadamente quando não se tem litígio.

Dentro de uma visão de meios adequados de solução de conflitos, proposto pelo Código de Processo Civil atual, tem-se que o fim é justamente diminuir a crescente pressão sobre os tribunais, que estão repletos de processos.

Em verdade, a atual formatação da sociedade, com informação abundante e o conhecimento de seus direitos, aliado ao acesso à justiça como garantia fundamental, tornou imprescindível se buscar meios que promovam soluções adequadas de conflitos à vista da pacificação social, deixando-se de lado a ideia do processo como meio exclusivo e des- 
concentrando-se a atuação da máquina do Judiciário, notadamente das questões de menor complexidade.

Consequentemente, a desjudicialização busca evitar a intervenção judicial nas situações em que isso não se faz necessário.

A tendência que se esboça, e isso num horizonte não muito distante, é a de deixar ao Judiciário somente os casos de pretensão resistida, em que o juiz atuará como mediador e substituto da vontade das partes. A desjudicialização será cada vez mais frequente naqueles casos em que as partes estiverem concordes, os interesses forem disponíveis e a lei autorizar a solução extrajudicial. (MARQUESI, 2018, p. 62)

Por conseguinte, é primordial se utilizar de instrumentos que assegurem ao cidadão a prestação de uma tutela jurisdicional efetiva, de maneira que possa atender ao direito fundamental de acesso à Justiça. Nessa hipótese, o prazo satisfatório para a entrega da tutela exerce papel essencial, sendo pressuposto da satisfação das contendas derivadas das mudanças do mundo moderno.

Diante dos obstáculos enfrentados pelo Poder Judiciário em atender com agilidade as demandas judiciais que a sociedade produz todos os dias, bem como da necessidade de encontrar soluções eficazes, a desjudicialização, pouco a pouco, começou a se tornar uma realidade no país.

De fato, seja por meio de leis ou por resoluções do Conselho Nacional de Justiça, a busca pela desjudicialização dos conflitos é uma realidade. E uma das formas que favorecem e incentivam a composição de situações sociais se dá exatamente por meio dos serviços extrajudiciais, buscando desta forma a possibilidade em desafogar o Poder Judiciário.

Exemplo disso está na separação e divórcio extrajudicial, inventário extrajudicial, a retificação da matrícula do imóvel diretamente no cartório, possibilidade de retificação do nome no registro civil para adequado à identidade de gênero diretamente no cartório, e a usucapião extrajudicial, tema do estudo.

Tais exemplos simbolizam uma preciosa cooperação do legislador para atenuar, a carga de processos e proporcionar soluções mais rápidas para as ações pretendidas, além de atestarem progresso no direito pátrio.

\section{A USUCAPIÁO EXTRAJUDICIAL DE BENS IMÓVEIS EM LINHAS GERAIS}

De praxe, a usucapião é, em regra, declarada mediante processo judicial que, atualmente, segue o procedimento comum do Código de Processo Civil de 2015, tendo em conta que a nova legislação, pôs fim ao procedimento especial da ação de usucapião.

Em verdade, essa estrutura processual é facilmente notada nos artigos que tratam da usucapião, como por exemplo, o artigo 1.238, que se refere à usucapião extraordinária. Por ele, adquire a propriedade aquele que possuir como seu por quinze anos sem interrupção, nem oposição, determinado imóvel, independentemente de título e boa-fé, "podendo requerer 
ao juiz que assim o declare por sentença, a qual servirá de título para o registro no Cartório de Registro de Imóveis" (BRASIL, 2002).

Observa-se, portanto, que o procedimento regra é o judicial. Mas, a partir de 2009, estabeleceu-se a possibilidade da usucapião ser obtida extrajudicialmente ou de forma administrativa.

De fato, a Lei Federal n. 11.977/2009, conhecida como Lei do Programa Minha Casa Minha Vida, já trazia, em seu art. $60^{9}$, a possibilidade do reconhecimento da aquisição originária da propriedade por possuidores de imóveis em locais suscetíveis a programas de regularização fundiária, sem qualquer intervenção judicial (BRASIL, 2009).

Mais atual, o Código de Processo Civil de 2015, dentro do seu espírito inovador de melhor resolver os conflitos, o que se verá mais adiante, trouxe uma grande alteração e atualização na possibilidade de reconhecimento extrajudicial ou administrativa da usucapião.

Deveras, o artigo 1.071 do Código de Processo Civil introduziu o artigo 216-A na Lei dos Registros Públicos (LF n. 6.015/1973), admitindo a usucapião extrajudicial, que será processada diretamente no Cartório de Registro de Imóveis da comarca em que o imóvel esteja localizado.

Art. 216-A. Sem prejuízo da via jurisdicional, é admitido o pedido de reconhecimento extrajudicial de usucapião, que será processado diretamente perante o cartório do registro de imóveis da comarca em que estiver situado o imóvel usucapiendo, a requerimento do interessado, representado por advogado, instruído com:

I - ata notarial lavrada pelo tabelião, atestando o tempo de posse do requerente e seus antecessores, conforme o caso e suas circunstâncias;

II - planta e memorial descritivo assinado por profissional legalmente habilitado, com prova de anotação de responsabilidade técnica no respectivo conselho de fiscalização profissional, e pelos titulares de direitos reais e de outros direitos registrados ou averbados na matrícula do imóvel usucapiendo e na matrícula dos imóveis confinantes;

III - certidões negativas dos distribuidores da comarca da situação do imóvel e do domicílio do requerente;

IV - justo título ou quaisquer outros documentos que demonstrem a origem, a continuidade, a natureza e o tempo da posse, tais como o pagamento dos impostos e das taxas que incidirem sobre o imóvel. (BRASIL, 1973)

Observa-se que a ideia do legislador foi, de fato, criar uma nova forma de se reconhecer a usucapião, extrajudicialmente ou administrativamente. E o fez de maneira "completamente distinta e sem dúvidas mais eficaz da prevista na Lei 11.977 de 07/07/2009" (HABERMANN JUNIOR; HABERMANN, 2018, p. 100).

Agora, atendendo os requisitos da lei material e do artigo 216-A da Lei de Registros Públicos, o interessado, reunindo os documentos que comprovam sua posse, bem como suas circunstancias e o lapso temporal e, ainda, a "ausência de ação reivindicando o imóvel, apresenta a documentação ao tabelião da localidade, do qual, após examiná-la, lavra uma

9 A redação original do artigo trazia que "sem prejuízo dos direitos decorrentes da posse exercida anteriormente, o detentor do título de legitimação de posse, após 5 (cinco) anos de seu registro, poderá requerer ao oficial de registro de imóveis a 
ata notarial, documento pelo qual atesta publicamente a existência da posse e suas características" (HABERMANN JUNIOR; HABERMANN, 2018, p. 100).

Esse procedimento extrajudicial "pode ocorrer em qualquer espécie de usucapião, desde que tenha como objeto bens imóveis e que não haja litígio" (BOCZAR; ASSUNÇÃO, 2018, p. 78). Contudo, como se observa da própria redação do artigo 216-A, "apesar de se tratar de jurisdição voluntária, a lei exige que o interessado esteja, obrigatoriamente, representado por advogado. Tal exigência se justifica para dar maior efetividade ao procedimento" (BOCZAR; ASSUNÇÃO, 2018, p. 79).

Anote-se que a usucapião extrajudicial será reconhecida mediante requerimento perante o Registro de Imóveis, com a apresentação de todos os documentos exigidos pelos incisos do artigo citado e ainda, instituídos por uma ata notarial lavrada pelo tabelião de notas.

Essa ata nada mais é do que uma narrativa de forma objetiva de um fato que foi verificado ou presenciado pelo notário, sem emitir juízo de valor. Poderá ela "ser feita em qualquer cartório de notas do país, sendo, posteriormente, encaminhada ao competente Cartório de Registro de Imóveis - juntamente com os documentos exigidos nos incisos I a IV do mencionado artigo - para o seu processamento" (ASSIS NETO; JESUS; MELO, 2017, p. 1.420).

Outro ponto de destaque para o procedimento administrativo em cartório é a necessidade de instruí-lo com a "planta e memorial descritivo assinado por profissional legalmente habilitado, com prova de anotação de responsabilidade técnica no respectivo conselho de fiscalização profissional, e pelos titulares de direitos reais e de outros direitos registrados ou averbados na matrícula do imóvel usucapiendo e na matrícula dos imóveis confinantes". Isso, logicamente, para garantir segurança ao procedimento e certeza naquilo que está sendo objeto de usucapião.

Todavia, na forma do art. $216-\mathrm{A}, \S 2^{\circ}$, se na planta e memorial descritivo faltar assinatura de qualquer um dos titulares de direitos reais ou de outros direitos registrados ou averbados na matrícula do imóvel usucapiendo e dos imóveis confinantes, "esse será notificado pelo registrador competente, pessoalmente ou pelo correio com aviso de recebimento, para manifestar seu consentimento expresso em 15 (quinze) dias, interpretado o silêncio como concordância" (BRASIL, 1973).

Fica claro, pelo texto da lei, que o silêncio de tais pessoas ao não assinar a planta e memorial descritivo, permanecendo inertes, significa concordância em relação aos seus termos. Logo, aqui quem cala consente ${ }^{10}$.

Importante destacar que a redação original do artigo era no sentido contrário, ou seja, o silêncio importava em discordância, o que causava uma série de empecilhos. Essa redação foi alterada pela Lei Federal n. 13.465, de 2017.

A presença desse requisito "revela a natureza consensual da usucapião" (MARQUESI, 2018, p. 79), pois exige a anuência do proprietário do imóvel usucapiendo, assim como a dos proprietários dos imóveis confinantes, podendo, no caso deles, ser tácita.

10 Sobre esse tema, "é conhecido o aforismo de que 'quem cala consente'. Mas, na verdade, quem cala nada diz. Cuida-se da aplicação do artigo 111 do Código Civil, que, a respeito da manifestação de vontade, enuncia que o 'silencio importa anuência, quando as circunstâncias ou os usos o autorizarem, e não for necessária a declaração de vontade expressa'" (MARQUESI, 2018, p. 105). 
Aquela Lei Federal de 2017 incluiu ainda algumas situações excepcionais. Primeiro, na forma do $\S 11$, em se tratando de imóvel em unidade autônoma de condomínio edilício, como um apartamento, por exemplo, "fica dispensado consentimento dos titulares de direitos reais e outros direitos registrados ou averbados na matrícula dos imóveis confinantes e bastará a notificação do síndico para se manifestar na forma do $\S 2^{\circ}$ deste artigo" (BRASIL, 1973).

Além disso, como manda o § 12, "se o imóvel confinante contiver um condomínio edilício, bastará a notificação do síndico para o efeito do $\S 2^{\circ}$ deste artigo, dispensada a notificação de todos os condôminos" (BRASIL, 1973).

Outro ponto importante acrescentado está no $\S 13$, pelo qual se a pessoa a ser notificada não foi encontrada ou se ela estiver em lugar incerto, não se sabendo seu atual endereço, "tal fato será certificado pelo registrador, que deverá promover a sua notificação por edital mediante publicação, por duas vezes, em jornal local de grande circulação, pelo prazo de quinze dias cada um, interpretado o silêncio do notificando como concordância" (BRASIL, 1973). Esse edital poderá ser feito por meio de em meio eletrônico, se assim regulamentado pelo órgão de correição das serventias, "caso em que ficará dispensada a publicação em jornais de grande circulação" (BRASIL, 1973), na forma do § 14.

Demais disso, a Lei traz também como requisito no inciso III as "certidões negativas dos distribuidores da comarca da situação do imóvel e do domicílio do requerente" (BRASIL, 1973). De conseguinte, "se a lei manda extrair certidões dos distribuidores, fica claro que se quer apurar a existência de processos judiciais que possam influir na aquisição do imóvel pela usucapião. É de entender que as certidões referem-se tanto à pessoa do proprietário como à do requerente" (MARQUESI, 2018, p. 89).

Outro requisito, presente no inciso IV é a prova do "justo título ou quaisquer outros documentos que demonstrem a origem, a continuidade, a natureza e o tempo da posse, tais como o pagamento dos impostos e das taxas que incidirem sobre o imóvel" (BRASIL, 1973).

Esse requisito deve "ser entendido como necessário somente na usucapião ordinária de imóveis, cediço que ante a falta de previsão legal, as demais espécies de usucapião não exigem" (MARQUESI, 2018, p. 90).

Nesse tocante, a Lei Federal n. 13.465, de 2017 acrescentou o § 15 no art. 216-A, facilitando a produção da prova exigida no inciso IV. Agora, se ausente ou insuficiente tais documentos, "a posse e os demais dados necessários poderão ser comprovados em procedimento de justificação administrativa perante a serventia extrajudicial" (BRASIL, 1973).

Trata-se de mais uma inovação da Lei, agora extrajudicializando o procedimento da justificação que "obedecerá, no que couber, ao disposto no $\S 5^{\circ}$ do art. 381 e ao rito previsto nos arts. 382 e 383 da Lei no 13.105, de 16 março de 2015" (BRASIL, 1973).

Compreendido seus requisitos, importante destacar que essa forma de procedimento extrajudicial é facultativa, como o próprio legislador destacou no início do artigo 216-A. Logo, a parte interessada "poderá optar pela propositura da ação judicial ainda que não haja litígio, e integra o fenômeno da desjudicialização do direito, no qual se inserem, por exemplo, dentre outros, o inventário e o divórcio extrajudiciais" (GONÇALVES, 2018, p. 223). Mesmo porque, ante a garantia fundamental do acesso à justiça e da inafastabilidade da apreciação do Poder Judiciário, presente no artigo $5^{\circ}$, inciso XXXV, da Constituição Federal, "a lei não excluirá da apreciação do Poder Judiciário lesão ou ameaça a direito" (BRASIL, 1988). 
Tendo o interessado optado por ele e formulado o requerimento, mediante representação de advogado e instruído com os documentos mencionados, na forma do artigo 216-A, $\S 1^{\circ}$, "o pedido será autuado pelo registrador, prorrogando-se o prazo da prenotação até o acolhimento ou a rejeição do pedido" (BRASIL, 1973).

Em sequência, cumprindo o $\S 3^{\circ}$ daquele artigo, "o oficial de registro de imóveis dará ciência à União, ao Estado, ao Distrito Federal e ao Município, pessoalmente, por intermédio do oficial de registro de títulos e documentos, ou pelo correio com aviso de recebimento, para que se manifestem, em 15 (quinze) dias, sobre o pedido" (BRASIL, 1973).

Empós, "o oficial de registro de imóveis promoverá a publicação de edital em jornal de grande circulação, onde houver, para a ciência de terceiros eventualmente interessados, que poderão se manifestar em 15 (quinze) dias" (BRASIL, 1973).

Transcorrido esse prazo e estando a documentação em ordem e não havendo qualquer impugnação, "o oficial de registro de imóveis registrará a aquisição do imóvel com as descrições apresentadas, sendo permitida a abertura de matrícula, se for o caso" (BRASIL, 1973), como dispõe o $\S 6^{\circ}$ daquele artigo.

Entrementes, o § $8^{\circ}$ estabelece que "se a documentação não estiver em ordem, o oficial de registro de imóveis rejeitará o pedido" (BRASIL, 1973), sendo possível, em qualquer caso, ao "interessado suscitar o procedimento de dúvida, nos termos desta Lei" (BRASIL, 1973).

Sempre bom lembrar que, na forma do $\S 9^{\circ}$, "a rejeição do pedido extrajudicial não impede o ajuizamento de ação de usucapião" (BRASIL, 1973). Como dito, "entendimento contrário disso importaria em violação à garantia do acesso formal à justiça, insculpida no art. XXXV, da Constituição Federal" (MARCHETTI FILHO, 2018a, p. 99).

\section{A APLICABILIDADE PRÁTICA DA USUCAPIÁO EXTRAJUDICIAL}

Esgotada a discussão sobre os meios adequados de solução de conflitos, compreendido um pouco sobre o fenômeno da desjudicialização e a disciplina legal da usucapião extrajudicial com seu procedimento, deve-se analisar a aplicabilidade prática desse instituto.

Nesse aspecto, a doutrina tem destacado que diante de algumas situações apresentadas dentro do procedimento administrativo e também na cultura da sociedade, a aplicabilidade da usucapião extrajudicial tem sido mitigada.

É dizer, casos que poderiam ser facilmente resolvidos no procedimento da usucapião extrajudicial, deixam de ser por vários aspectos e acabam tornando-se um processo contencioso no Judiciário.

Os obstáculos para a ampla adoção do modelo consensual de abordagem de conflitos são muitos, podendo ser aduzidos como centrais os seguintes óbices: 1. a formação acadêmica de operadores do Direito, que não contempla tal sistemática; 2. a falta de informação sobre a disponibilidade de meios consensuais; 3 . o receio da perda de poder de autoridade das instituições tradicionais de distribuição de justiça. (TARTUCE, 2018, p. 110) 
Nessa linha de contada, apontar-se-á, a seguir, alguns fatores que tornam ineficaz a aplicação prática da usucapião extrajudicial.

\subsection{A CULTURA LITIGIOSA}

A mudança de mentalidade e o esforço da comunidade jurídica relativamente ao fomento dos meios adequados de solução de litígios para a pacificação do conflito é imprescindível na sociedade moderna, notadamente no Estado Constitucional de Direito, dentro da visão de um acesso à justiça efetivo, justo, eficiente e adequado.

Nesse tocante, foram materializadas relevantes inovações legislativas nos últimos anos, notadamente em 2015, com o novo Código de Processo Civil (Lei Federal n. 13.105/2015), a reforma pontual da Lei de Arbitragem (Lei Federal n. 13.129/2015) e a Lei da Mediação (Lei Federal n. 13.140/2015).

Interessante notar que, replicando a Constituição Federal, o Código de Processo Civil de 2015 dispõe, no art. $3^{\circ}$, que "não se excluirá da apreciação jurisdicional ameaça ou lesão a direito" (BRASIL, 2015). Mas, dentro desse aspecto, traz para dentro do processo civil a ideia dos meios adequados de solução de conflitos ao consignar que o processo não é o único caminho a seguir.

Por isso, enfatiza, nos $\S \S 1^{\circ}$ a $3^{\circ}$, que "é permitida a arbitragem, na forma da lei" (BRASIL, 2015) e "o Estado promoverá, sempre que possível, a solução consensual dos conflitos" (BRASIL, 2015). Mas essa promoção não é dever apenas do Estado. "A conciliação, a mediação e outros métodos de solução consensual de conflitos deverão ser estimulados por juízes, advogados, defensores públicos e membros do Ministério Público, inclusive no curso do processo judicial" (BRASIL, 2015).

Assim sendo, o novel diploma processual determina aos Tribunais a criação de centros judiciários de solução consensual de conflitos, com a capacitação de conciliadores e mediadores para atender a demanda de conflitos presentes no judiciário.

Mas não é só. Trouxe também aspectos importantes relativos à solução extrajudicial do conflito por meio de procedimentos administrativos diretamente no cartório, como no inventário extrajudicial (CPC, art. $610, \S \S 1^{\circ}$ e $2^{\circ}$ ), no divórcio, separação e extinção de união estável de forma consensual pela via extrajudicial (CPC, art. 733) e a usucapião extrajudicial, inserida mediante a criação do artigo 216-A na Lei de Registros Públicos (CPC, art. 1.071).

Contudo, a aplicabilidade prática desses institutos, notadamente da usucapião extrajudicial é mínima. E um dos fatores está exatamente na cultura da litigiosidade arraigada na sociedade brasileira, fator esse que se reflete no próprio ensino jurídico e na atuação do profissional.

Em verdade, a despeito de a lei exigir a participação de um advogado no procedimento da usucapião extrajudicial, o fato é que os operadores do direito, não só nos bancos escolares, mas também em sua vida profissional, não são incentivadores da adoção de medidas de soluções adequadas e solução de conflitos de forma extrajudicial, seja por desinteresse próprio, ou por descrença da parte que atende. 
Na formação do bacharel em Direito, a ênfase do estudo acaba sendo prioritariamente centrada no exercício da jurisdição estatal contenciosa, o que gera certa negligência no trato de meios consensuais. Reforçados os fundamentos do processo como instrumento de Direito público, acabou-se consolidando o entendimento de que, a partir da atuação do Estado e de seu elemento capaz de submeter uma das partes à pretensão da outra, justo é o que o Estado determina e faz cumprir. (TARTUCE, 2018, p 112)

Isso é, pois, reflexo da cultura da litigiosidade e da espera de resultados apenas de sentenças judiciais que está impregnada na sociedade brasileira. "Nessa linha de contada, a inexistência de formação dos operadores do direito voltada aos meios adequados de solução de conflitos, 'sobretudo de bases consensuais, constitui um grande empecilho a ser superado no desenvolvimento de uma cultura de paz"' (MARCHETTI FILHO, 2018c, p. 247)

Assim, apesar de todos os avanços legislativos que incentivam a aplicabilidade das medidas adequadas das soluções de conflito e a busca pelo processo de desjudicialização, os operadores do direito estão em descompasso com essa prática.

Nessa trajetória relacional, a simples mudança legislativa não importará qualquer transformação no quadro atual se não acompanhada da quebra do paradigma social que se vive no Brasil. A modificação na forma de pensar da sociedade em geral, desde o cidadão comum até os operadores do direito e responsáveis pela administração pública em geral e da justiça, principalmente, é imprescindível. (MARCHETTI FILHO, 2018c, p. 242).

Portando, não há falar apenas em mudança da lei para se ter o incentivo na adoção de meios adequados de conflitos, principalmente a solução de conflitos pelo procedimento extrajudicial. É imprescindível também a mudança cultural, a transformação social para se levar a adoção desses meios.

\subsection{OS EMOLUMENTOS DEVIDOS}

Além da problemática envolvendo a cultura da litigiosidade e a falta de preparo ou desinteresse para se promover a solução adequada do conflito do profissional do direito, tem-se ainda obstáculos na própria linha procedimental. E um deles se refere ao valor dos emolumentos cobrados no serviço notarial, ou seja, o custo de um procedimento extrajudicial.

A Lei Federal n. 10.169, de 2000, estabelece as normas gerais para a fixação de emolumentos relativos aos atos praticados pelos serviços notariais e de registro. Dessa forma, nos termos do artigo $1^{\circ}$, "os Estados e o Distrito Federal fixarão o valor dos emolumentos relativos aos atos praticados pelos respectivos serviços notariais e de registro, observadas as normas desta Lei" (BRASIL, 2000), sendo que, pelo parágrafo único, esse valor "deverá corresponder ao efetivo custo e à adequada e suficiente remuneração dos serviços prestados" (BRASIL, 2000).

Para além disso, 0 art. $2^{\circ}$ da Lei estabelece os parâmetros que devem ser utilizados para a fixação dos emolumentos, destacando:

Art. $2^{\circ}$ Para a fixação do valor dos emolumentos, a Lei dos Estados e do Distrito Federal levará em conta a natureza pública e o caráter social dos serviços notariais e de registro, atendidas ainda as seguintes regras: 
I - os valores dos emolumentos constarão de tabelas e serão expressos em moeda corrente do País;

II - os atos comuns aos vários tipos de serviços notariais e de registro serão remunerados por emolumentos específicos, fixados para cada espécie de ato;

III - os atos específicos de cada serviço serão classificados em:

a) atos relativos a situações jurídicas, sem conteúdo financeiro, cujos emolumentos atenderão às peculiaridades socioeconômicas de cada região;

b) atos relativos a situações jurídicas, com conteúdo financeiro, cujos emolumentos serão fixados mediante a observância de faixas que estabeleçam valores mínimos e máximos, nas quais enquadrar-se-á o valor constante do documento apresentado aos serviços notariais e de registro. (BRASIL, 2000)

Ademais, a Lei veda expressamente, no art. $3^{\circ}$, inciso II, a fixação de "emolumentos em percentual incidente sobre o valor do negócio jurídico objeto dos serviços notariais e de registro" (BRASIL, 2000).

Assim, basicamente e no campo prático, cada Tribunal de Justiça estadual é responsável pela tabela de preços dos serviços notariais e de registro do seu respectivo Estado. Os valores de cada atividade são calculados e, se houver necessidade de algum reajuste, um Projeto de Lei com a nova tabela de preços é encaminhado para o legislativo estadual para aprovação, observando-se o princípio da anterioridade.

Entrementes, na prática, esses valores se mostram muito superiores ao custo de uma demanda judicial. Seja porque no procedimento extrajudicial não há os benefícios da justiça gratuita; seja porque, mesmo no tocante à "justiça paga", não são poucas às vezes em que as custas do processo se mostram muito inferiores ao valor dos emolumentos cobrados pelo serviço notarial.

Apenas a título exemplificativo, no Estado de Mato Grosso do Sul, a Lei n. 3.003, de 2005, não traz qualquer previsão das custas para o procedimento de usucapião extrajudicial. Mas, para se registrar uma sentença declaratória de usucapião, os emolumentos são de $\mathrm{R} \$ \mathbf{9 2 , 0 0}$ (tabela III.C, anexo à Lei ${ }^{11}$ ).

Ademais, a simples análise da Tabela I do Anexo da Lei Estadual mostra a cobrança de emolumentos escalonados conforme o valor declarado no negócio para a lavratura de escrituras públicas, podendo chegar a R\$ 7.847,00, o que, por óbvio, é muito dispendioso e desestimula a prática do procedimento extrajudicial, considerando que as custas do processo de usucapião não chega nem a metade desse valor. Isso quando não se tem os benefícios da justiça gratuita.

\subsection{A RECUSA DO REGISTRADOR}

O último ponto que se destaca nesse estudo e que gera o desestímulo para o uso do procedimento extrajudicial da usucapião está exatamente no próprio procedimento. Isso porque, nos termos do $\S 8^{\circ}$, do artigo 216 -A, da Lei de Registros Públicos, "ao final das dili- 
gências, se a documentação não estiver em ordem, o oficial de registro de imóveis rejeitará o pedido" (BRASIL, 1973).

Traduzindo isso e dentro da ideia do procedimento do art. 216-A, a falta de concordância expressa de alguma das pessoas indicadas no inciso II - seja por interesse conflituoso, ou por desinteresse no assunto, ou ainda por maldade ou vingança - gera, impreterivelmente, a rejeição do requerimento administrativo.

E mais, como dispõe o $\S 9^{\circ}$, "a rejeição do pedido extrajudicial não impede o ajuizamento de ação de usucapião" (BRASIL, 1973). Não que isso esteja errado. Pelo contrário. É correto, mesmo porque a lei não pode excluir qualquer assunto da apreciação do Poder Judiciário, na forma do art. $5^{\circ}$, inciso XXXV, da Constituição Federal (BRASIL, 1988).

Porém, o efeito prático e lógico disso é que se, depois de todo o trabalho e custo, há o risco de rejeição pelo simples fato de se ter uma impugnação infundada, então melhor é ingressar diretamente com a ação de usucapião.

Demais disso, o $\S 10^{12}$ consigna que havendo impugnação ao reconhecimento extrajudicial, o oficial deverá remeter os autos ao Juízo da comarca onde o imóvel esteja localizado. E, convertido em ação de usucapião, a parte deverá emendar a inicial para adequá-la ao procedimento comum do Código de Processo Civil.

Em outras palavras, ao final de todo o trabalho, em razão de uma simples impugnação, às vezes completamente sem fundamento, o que era para ser um simples procedimento extrajudicial, acaba se tornando um contencioso civil, um processo de usucapião.

Isso tudo faz com que o requerente volte à estaca zero, estando obrigado a enfrentar, além do tempo perdido no procedimento extrajudicial, a demora do processo. Isso, por óbvio, acaba por tornar a usucapião extrajudicial inviável.

\section{CONSIDERAÇÓES FINAIS}

Como visto, a propriedade é um direito fundamental da pessoa, garantido constitucionalmente. Mas, ao contrário do que era outrora, hoje seu exercício não é mais absoluto. Isso porque, ao mesmo tempo em que a Constituição Federal a garante como direito fundamental, também traz o ônus de que o exercício dessa propriedade deve atender uma função social.

Diante disso, tem-se que o instituto da usucapião evoluiu sobremaneira, ganhando nova base de fundamentação, agora constitucional, voltada para a função social. É dizer, a usucapião busca entregar a propriedade da coisa para aquele que efetivamente está exercendo a função social da propriedade, pelo menos no exercício básico de seus poderes.

12 "Art. 216-A. [...]

$\S 10$. Em caso de impugnação do pedido de reconhecimento extrajudicial de usucapião, apresentada por qualquer um dos titulares de direito reais e de outros direitos registrados ou averbados na matrícula do imóvel usucapiendo e na matrícula dos imóveis confinantes, por algum dos entes públicos ou por algum terceiro interessado, o oficial de registro de imóveis remeterá os autos ao juízo competente da comarca da situação do imóvel, cabendo ao requerente emendar a petição inicial para adequá-la ao procedimento comum" (BRASIL, 1973). 
De outro norte, sabe-se que, em regra, a declaração da usucapião deve se dar por sentença judicial, que será levada à registro, após a tramitação de um processo que seguirá, pela atual sistemática do Código de Processo Civil de 2015, o procedimento comum.

Entrementes, sabe-se que o Poder Judiciário, na sociedade moderna, não tem condições de atender a grande carga de demandas que diariamente ingressam por seus sistemas virtuais, o que gera uma lentidão para a prestação jurisdicional.

Isso, logicamente, gera um prejuízo para o acesso à justiça efetivo, justo e eficiente, que devem permear o processo sob a visão constitucional do Estado de Direito, notadamente para aquelas causas que são de simples solução e não tem litígio manifesto.

Foi nesse intuito que o Código de Processo Civil de 2015 buscou, dentro de uma moderna visão de pacificação dos conflitos sociais, afastar a ideia de processo como único meio de solução de conflito.

Em verdade, o Código partiu da premissa de que o processo é apenas mais um meio, dentre vários disponíveis para a solução dos conflitos sociais. Nessa pegada, trouxe a ideia da adequação dos meios de solução de conflito para se promover a pacificação social.

Diante disso, além de trazer a conciliação, a mediação e a arbitragem para dentro do processo civil, também firmou o fenômeno da desjudicialização dos conflitos, dando aos serviços notariais a possibilidade de solucionar conflitos, notadamente os que envolvem separação, divórcio, dissolução de união estável, inventário e, agora, a usucapião extrajudicial, por meio da criação do artigo 216-A na Lei de Registros Públicos.

Tal artigo traz todo o procedimento administrativo que deve ser seguido no serviço notarial, desde os requisitos do requerimento, os documentos e assinaturas necessárias e seu desfecho, com o registro da usucapião ou sua rejeição, além da possibilidade de conversão para processo judicial, caso haja impugnação.

Entrementes, algumas questões colocam em risco a efetividade desse procedimento. Aqui, foram apontados três pontos principais. Primeiro, a cultura do litígio e a falta de confiança dos profissionais do direito e da própria sociedade em outros meios de solução de conflitos que não o processo. E isso atinge a aplicabilidade da desjudicialização dos conflitos.

Em segundo, tem-se o custo dos serviços notariais no Brasil que é elevado e, por vezes, supera o custo do processo, notadamente quando nele se tem a possibilidade da gratuidade da justiça, enquanto que no procedimento administrativo extrajudicial os emolumentos sempre são cobrados. Logo, ainda que mais rápido, o valor para se obter a solução acaba tornando mais atraente o processo, ainda que a tutela jurisdicional demore para ser obtida.

Por fim, em terceiro, destaca-se um problema no próprio procedimento. Isso porque, a despeito de todas as melhorias vindas no procedimento administrativo com a Lei Federal $\mathrm{n}$. 13.465, de 2017, ainda há a dificuldade apontada no sentido de que a existência de impugnação, ainda que manifestamente infundada, faz com o que oficial de registro encaminhe o procedimento para o Judiciário.

Em outro falar, seja como for, havendo rejeição ou impugnação, será necessário o processo para dirimir o conflito. E o raciocínio para a parte é simples: apenas perdeu-se tempo e dinheiro. 
Nessa ordem de ideais, apesar de interessante e com o objetivo de promover a solução do conflito de forma mais simples e rápida, o fato é que, em relação à usucapião, o procedimento acaba não tendo a aplicabilidade que poderia ter pelos fatores apresentados.

De conseguinte é imprescindível, para uma melhor aplicação, promover-se a propagação, na sociedade e nos profissionais, da importância da adequação do meio de solução de conflito com o fim de se ter a pacificação social, retirando-se a ideia de que o processo é o único meio de solução.

Ademais, é preciso promover uma desoneração do procedimento para, do ponto de vista econômico, se tornar mais interessante, além de realizar-se, no campo legislativo, uma adequação do procedimento para viabilizar ainda mais a sua materialização.

\section{REFERÊNCIAS}

ASSIS NETO, S.; JESUS, M. de; MELO, M. I. Manual de direito civil. 6. ed. Salvador: Juspodivm, 2017.

AZEVEDO, A. G. de (Org.). Manual de mediação judicial. 5. ed. Brasília: CNJ, 2015.

BOCZAR, A. C. A. A.; ASSUNÇÃO, L. F. M. Usucapião extrajudicial: questões notariais e tributárias. São Paulo: JH Mizuno, 2018.

BRASIL. Constituição (1988). Constituição da República Federativa do Brasil: promulgada em 5 de outubro de 1988. Disponível em: http://www.planalto.gov.br/ccivil_03/Constituicao/Constituicao.htm. Acesso em: 25 jul. 2017.

Lei Federal n. 10.169, de 29 de dezembro de 2000. Regula o § $2^{\circ}$ do art. 236 da Constituição Federal, mediante o estabelecimento de normas gerais para a fixação de emolumentos relativos aos atos praticados pelos serviços notariais e de registro. Diário Oficial [da] República Federativa do Brasil, Brasília, 30 dez. 2000.

. Lei Federal n. 10.406, de 10 de janeiro de 2002. Institui o Código Civil. Diário Oficial [da] República Federativa do Brasil, Brasília, 11 jan. 2002.

. Lei Federal n. 11.977, de 7 de julho de 2009. Dispõe sobre o Programa Minha Casa, Minha Vida - PMCMV e a regularização fundiária de assentamentos localizados em áreas urbanas. Diário Oficial [da] República Federativa do Brasil, Brasília, 8 jul. 2009.

Lei Federal n. 13.105, de 16 de março de 2015. Código de Processo Civil. Diário Oficial [da] República Federativa do Brasil, Brasília, 17 mar. 2015.

. Lei Federal n. 6.015, de 31 de dezembro de 1973. Dispõe sobre os registros públicos, e dá outras providências. Diário Oficial [da] República Federativa do Brasil, Brasília, 31 dez. 1973.

CHALHUB, M. N. Propriedade imobiliária - Função social e outros aspectos. Rio de Janeiro: Renovar, 2000.

GODOY, C. L. B. de. Função social do contrato. São Paulo: Saraiva, 2004.

GONÇALVES, C. R. Direito civil brasileiro: direito das coisas. 12. ed. São Paulo: Saraiva, 2018. v. 5.

GONÇALVES, M. V. R. Direito processual civil esquematizado. 8. ed. Saraiva: São Paulo, 2017.

HABERMANN JUNIOR, C.; HABERMANN, R. T. Usucapião judicial e extrajudicial no novo CPC. 2. ed. São Paulo: Habermann, 2018.

MARCHETTI FILHO, G. F. Estudos de direito - Direito Civil: Direito das coisas. Campo Grande: Contemplar, $2018 \mathrm{a}$. Estudos de Direito - Direito Civil: teoria geral dos contratos. Campo Grande: Contemplar, $2018 \mathrm{~b}$. 
Os Direitos Fundamentais, a pacificação dos conflitos sociais e o Código de Processo Civil: 0 novo paradigma do Processo Civil em vista do acesso à justiça efetiva, justa, eficiente e adequada. Campo Grande: Contemplar, 2018c.

MARQUESI, R. W. Usucapião extrajudicial. 2. ed. Curitiba: Juruá, 2018.

MAZZA, A. Manual de direito administrativo. São Paulo: Saraiva, 2015.

PEREIRA, C. M. da S. Instituições de direito civil: direitos reais. 19. ed. Rio de Janeiro: Forense, 2008. v. 4.

TARTUCE, F. Mediação dos Conflitos Civis. 4. ed. Rio de Janeiro: Forense; São Paulo: Método, 2018.

THEODORO JÚNIOR, H. Curso de Direito Processual Civil: Teoria geral do direito processual civil, processo de conhecimento e procedimento comum. 56. ed. Forense, Rio de Janeiro, 2015. v. 1.

Recebido/Received: 23.07.2019

Aprovado/Approved: 07.05.2020 